\title{
EXTRACTION OF ELIONURUS HENSII K. SCHUM ESSENTIAL OIL IN A DOMESTIC SCALE IN THE "PLATEAU DES CATARACTES" (CONGO-BRAZZAVILLE)
}

\author{
Silou $T^{1,2^{*}}$, Nombault Nienzy JP ${ }^{1,2}$, Nsikabaka $S^{1,2}$, Loumouamou AN ${ }^{3,4}$, Bikindou $K^{3,4}$ \\ ${ }^{1}$ Faculté des Sciences ET Techniques, BP 69 Brazzaville, Congo \\ ${ }^{2}$ Ecole Supérieure de Technologie des Cataractes, BP 389, Brazzaville, Congo \\ ${ }^{3}$ Ecole Normale Supérieure B.P. 69 Brazzaville, Congo \\ ${ }^{4}$ Institut National de Recherche en Sciences Exactes ET Naturelles BP 2400 Brazzaville, Congo
}

DOI: https://doi.org/10.29121/IJOEST.v2.i1.2017.05

\begin{abstract}
Elionurus hensii yields essential oils composed mainly of para-menthadienols in its stems and about $50 \%$ aristo lone in its roots. These oils, which exhibit anti-microbial and anti-oxidant properties, were extracted by hydro distillation with a local extractor and was analyzed by gas chromatography (GC/FID and GC/MS).

To optimize this domestic process, a $2^{3}$ full factorial design is used to assess the effects and interactions of potentially influential factors. Stems yield 1-2\% in essential oil. The extraction time and the degree of division of the plant material had negligible effects on the yield. Only the residual water content had a significant positive effect, together with the interaction between this content and the degree of division. The cumulated content of the four isomeric paramenthadienols present in the oil was insensitive to the effects and interactions of the factors. Roots yield $0.5-0.9 \%$ in essential oil. The overall effects and interactions of factors on the yield and the aristo lone content were negligible.

Principal component analysis of samples obtained with the experimental design, and their radar plots, indicated a very strong resemblance between oils obtained from the same plant part, and a marked difference between those obtained from different plant parts.
\end{abstract}

Keywords: Experimental Design; Effects of Factor; Multivariate Analysis; P- Menthadienols; Aristo lone, Elionurus Hensii.

Cite This Article: Silou T, Nombault Nienzy, Nsikabaka S, Loumouamou AN, and Bikindou K. (2017). EXTRACTION OF ELIONURUS HENSII K. SCHUM ESSENTIAL OIL IN A DOMESTIC SCALE IN THE "PLATEAU DES CATARACTES" (CONGO-BRAZZAVILLE). International Journal of Engineering Science Technologies, 2(1), 37-57. doi: 10.29121/IJOEST.v2.i1.2017.05

\section{INTRODUCTION}

The genus Elionurus (Poaceae family), comprising some 20 species, is not well described in the literature. What work is reported concerns Elyonurus muticus [1], [2], [3], Elionurus elegans [4] and Elyonurus viridulus [5]. The essential oil derived from both the aerial parts (stems) and the below-ground parts (roots) of Elionurus elegans possesses antibacterial, antifungal and 
antioxidant properties [4]. The methanol extracts of Elyonorus muticus, composed mainly of phenolic compounds, exhibit a high antioxidant activity [6].

Elionurus hensii, which is found in tropical and subtropical regions of South America (Brazil and Argentina), Africa (Republic of Congo, Gabon, DR Congo, Angola) and Australia [8], has been studied only in the Republic of Congo, where this wild plant grows abundantly on the "Plateau des Cataractes".

In the first description we published in 2006 of the essential oils from different parts of the plant (roots, stems, leaves, flowers), we reported that the oils from the aerial parts were mainly composed of $p$-menthadienols, whereas the roots yielded an oil containing more than $40 \%$ aristolone [9].

In a previous very detailed study of (i) the volatile components from stems and roots obtained by hydrodistillation and head-space SPME, and (ii) the phenolic compounds and flavonoids extracted with methanol, ethyl acetate and dichloromethane, the antioxidant activities of the extracts were demonstrated and compared [8].

Loumouamou et al. assess the seasonal variation in the composition of essential oils as a function of different harvest sites, and the impact of this composition on the biological activities [10], [11], [12].

However, the massive presence of $p$-menthadienol isomers points to possible antimicrobial properties, as in Cymbopogon gigantus from Burkina Faso [13], Cameroon [14], Benin [15], Mali [16], and Côte d'Ivoire [17].

Further, aristolone, a ketone that is very abundant in the roots, could either be isolated or gainfully used in its native state, or after conversion into its oxime: several studies have found this family of substances to have antitumor, antimicrobial, antioxidant, and antidepressant, anticonvulsive and antiviral properties [18].

We describe here the essential oil extraction from stems and roots of Elionurus hensii, to assess the effects of factors controllable at the artisanal level on the yield and quality of the products obtained.

The results of this work will support controlled artisanal production of this oil, which is of potential medicinal interest, by essential oil producers grouped in the OIBT project as part of the Republic of Congo anti-poverty programme [19].

\section{MATERIALS AND METHODS}

\subsection{Plant Material}

Elionurus hensii K. Schum is a perennial grass composed of culms $60-100 \mathrm{~cm}$ long, with strongly developed side branches forming blades 7-10 cm long, 2-3 cm wide that flower at maturity [20], [21]. 
In the Republic of Congo, where it grows under the lower-Congo climate, on clay-sand to sandymoist soil, this plant, which does not exceed $1 \mathrm{~m}$ in height, presents upwardly branched culms, thin sinuous roots $4-8 \mathrm{~cm}$ long, rolled leaves $8-15 \mathrm{~cm}$ long and $2 \mathrm{~cm}$ wide, and a glabrous base.

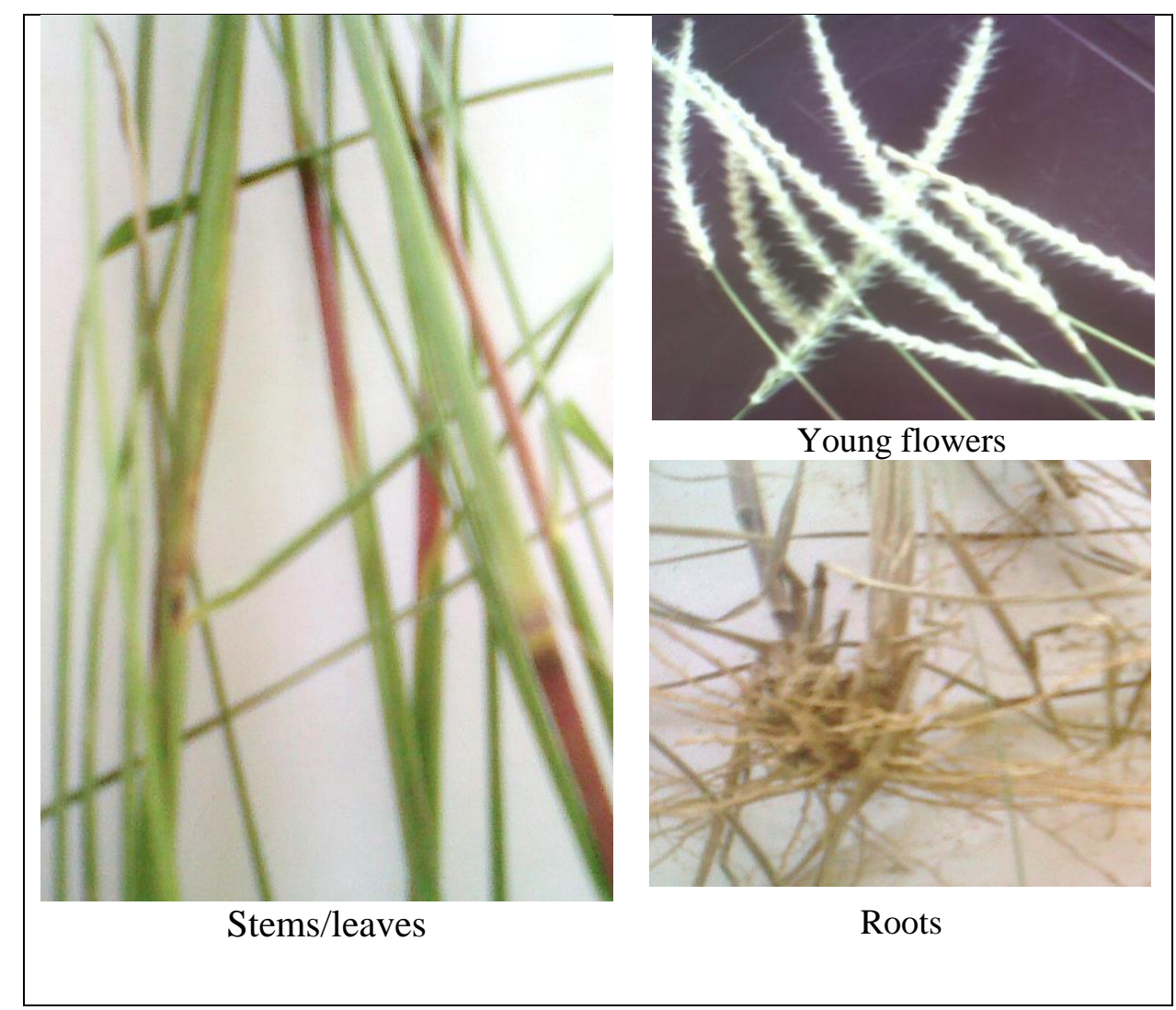

Figure 1: Fresh Plant of Elyonurus Hensii (Stems, Leaves, Flowers, Roots,)

The samples studied were collected on the "Plateau des Cataractes" at Loufoulakari, Loukoko and Sese (District of Louingui, Pool Department, R Congo).

\subsection{Extraction}

In the Laboratory scale, the essential oils were obtained by steam distillation. Water and plant material (200 g of plant material for stems, or $135 \mathrm{~g}$ for roots.) were placed in a Clevenger apparatus for $4 \mathrm{~h}$. The organic phase of the resulting condensate was separated from the aqueous phase by extraction with diethyl ether. The organic phase was dried over sodium sulphate and the essential oil was recovered after evaporation of the solvent.

The artisanal extraction is led in a cylindrical distiller $(60 \mathrm{~L}, 4 \mathrm{~kg})$. The vapor resulting from the hydrodistllation passes in a pipe $(2 \mathrm{~cm}$ diameter) crossing a $(100 \mathrm{~cm}$ length, $30 \mathrm{~cm}$ broad and 30 $\mathrm{cm}$ height) reserve, filled with cool water circulating in opposite direction (figure 2). 


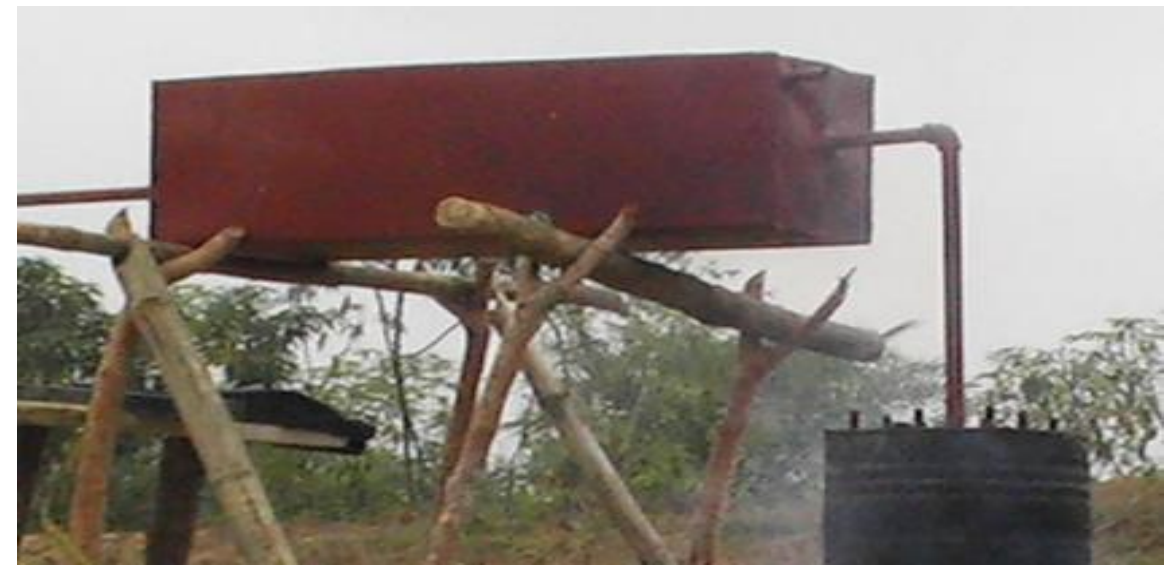

Figure 2: Local equipment for hydrodistillation of essential oils (60 L)

\subsection{Gaz Chromatography}

GC analysis was performed on an Agilent GC 6890 instrument equiped with a split injector $\left(280^{\circ} \mathrm{C}\right)$, a flam ionization detector (FID) and a DB-5 column $(20 \mathrm{~m} \times 0,18 \mathrm{~mm} \times 0,18 \mu \mathrm{m})$. The temperature program was $50^{\circ} \mathrm{C}(3.2 \mathrm{~min})$ rising to $330^{\circ} \mathrm{C}\left(10^{\circ} \mathrm{C} / \mathrm{min}\right)$. Dihydrogene was used as carrier at a flow rate $1 \mathrm{ml} / \mathrm{min}$.

\subsection{Gaz Chromatography / Mass Spectrometry}

GC/SM analysis was performed on Agilent GC 7890 /Agilent MS 5975 operating in EI mode (70 $\mathrm{eV})$, equiped with a DB-5 column $(20 \mathrm{~m} \times 0,18 \mathrm{~mm} \times 0,18 \mu \mathrm{m})$. The temperature of injector was $280^{\circ} \mathrm{C}$ and helium was the carrier gas at $0.9 \mathrm{~mL} / \mathrm{min}$. The temperature program was $50^{\circ} \mathrm{C}(3.2$ $\min )$ rising to $330^{\circ} \mathrm{C}\left(8^{\circ} \mathrm{C} / \mathrm{min}\right)$.

The identification was carried out by calculating retention indices (RI) and comparing mass spectra with those in data bancks [22], [23], [24], [25].

\subsection{Modelling of Essential Oil Extraction (Hydrodistillation)}

The variables influencing extraction yield were: time, temperature, condensation rate, the state of division of the plant material, the mass ratio of plant material to water, and water loss from plant material [26].

A model with six variables, even in the case of a first degree model, would need $2^{6}=64$ experiments [27]. For experimental convenience some variables were thus kept constant. We considered three variables: extraction duration, residual water content $\left(\mathrm{X}_{2}\right)$ and state of division of the plant material $\left(\mathrm{X}_{3}\right)$. These three factors offered the advantage of being easy to control, even in a small scale production unit. Extraction yield $\mathrm{y}$ and $p$ - menthadiol content $\mathrm{z}$ depend on factors $X_{1}, X_{2}$ and $X_{3}$. Mathematically, this is expressed as $y$ or $z=f\left(X_{1}, X_{2}, X_{3}\right)$ where $y$ and $z$ are the responses, $f(X)$ is the response function and $X_{1}, X_{2}$ and $X_{3}$, are the factors taken into account.

The experiment is designed to determine the effects of certain factors on each response. 
The two-level factorial design as developed by Davies [28] is well-suited to addressing this type of question, and has the advantage of needing only very elementary mathematical skills [29].The general formula for a complete factorial plan with $\mathrm{N}$ experiments is $\mathrm{N}=2^{\mathrm{k}}$, where $\mathrm{k}$ is the number of variables in the factorial. If $\mathrm{k}=3$, then $\mathrm{N}=2^{\mathrm{k}}=2^{3}=8$ experiments.

To construct the experiment matrix we define reduced variables $\mathrm{x}_{\mathrm{i}}$ as:

$\mathrm{X}_{\mathrm{i}}=\left(\mathrm{X}_{\mathrm{i}}-\mathrm{X}_{0}\right) / \Delta \mathrm{X} ; \mathrm{X}_{0}$ is the base value, at the centre of the experimental domain (level 0 ), and $\Delta \mathrm{X}$ is the variation step, i.e., the unit of variation of the variables. Table 1 give the two levels of the variables in steam extraction of Elionurus hensii stems.

Table 1: Levels of the variables in steam extraction of Elionurus hensii stems

\begin{tabular}{lccc}
\hline Level & Extraction duration (h) & Residual water content & State of division (cm) \\
& $\boldsymbol{X}_{\mathbf{1}}$ & $\boldsymbol{X}_{\mathbf{2}}$ & $\boldsymbol{X}_{\mathbf{3}}$ \\
\hline Low $(-1)$ & 1.5 & Low & $<5$ \\
High $(+1)$ & 3 & High & 10 \\
\hline
\end{tabular}

The combination of these 3 variables and the 2 levels by variable lead to the following experimental design (table 2)

Table 2: Experimental design for essential oil extraction from Elionurus hensii stems

\begin{tabular}{cccc}
\hline Run & $\mathbf{X}_{\mathbf{1}}(\mathbf{h})$ & $\mathbf{X}_{\mathbf{2}}$ & $\mathbf{X}_{\mathbf{3}}(\mathbf{c m})$ \\
\hline 1 & 1.5 & Low & $<5$ \\
2 & 3 & Low & $<5$ \\
3 & 1.5 & High & $<5$ \\
4 & 3 & High & $<5$ \\
5 & 1.5 & Low & 10 \\
6 & 3 & Low & 10 \\
7 & 1.5 & High & 10 \\
8 & 3 & High & 10 \\
\hline
\end{tabular}

The domain of the study, with coded variables, becomes the domain $(-1,+1)$ and the eight responses described by the experimental matrix are set up after randomisation (table 3 ).

Table 3: Experimental matrix for essential oil extraction from Elionurus hensii stems

\begin{tabular}{cccc}
\hline & Extraction duration (h) & Residual water content & State of Division \\
Run & $\mathbf{x}_{\mathbf{1}}$ & $\mathbf{x}_{\mathbf{2}}$ & $\mathbf{x}_{\mathbf{3}}$ \\
\hline 1 & -1 & -1 & -1 \\
2 & +1 & -1 & -1 \\
3 & -1 & +1 & -1 \\
4 & +1 & +1 & -1 \\
5 & -1 & -1 & +1 \\
6 & +1 & -1 & +1 \\
7 & -1 & +1 & +1 \\
8 & +1 & +1 & +1 \\
\hline
\end{tabular}


For a first degree model with interactions, the representative points of a three-variable experimental design are located in three-dimensional space. The corresponding response function is a first degree polynomial for each factor taken separately. It is notated:

$$
y=a_{0}+a_{1} x_{1}+a_{2} x_{2}+a_{3} x_{3}+a_{12} x_{1} x_{2}+a_{13} x_{1} x_{3}+a_{23} x_{2} x_{3}+a_{123} x_{1} x_{2} x_{3}
$$

If the mathematical model associated with the factorial design is constructed with centred, reduced variables, the coefficients of the polynomial thus have very simple meanings: average $a_{0}$, main effects $a_{i}$, and interactions $a_{i j}$, and $a_{i j k}$ [27].

\subsection{Statistical Treatment}

Means, standard deviations and the usual graphs were obtained with Excel software. Multivariate analysis was performed on XLSTAT software (Addinsoft an add up of Excel Microsoft).

\section{RESULTS AND DISCUSSION}

\subsection{Chemical Composition of Stem and Root Essential Oils of Elionurus Hensii}

Previously works show that the essential oils from all the aerial parts were similar, and were mostly composed of oxygenated monoterpenes, in particular $p$-menthadienols, and that those from the below-ground parts contained some $40 \%$ aristolone [9], [8]. In this study, all the aboveground parts were pooled to make a single sample, hereafter called "stems"; likewise for the below-ground parts, called "roots".

Tables 4 and 5 show respectively chemical composition of stem and root essential oils from Elionurus hensii, table 6 recapiulates the main constituents of stem and root essential oils from Loufoulakari, Loukoko and Sese sites.

Table 4: Chemical composition of the essential oil from stems of Elionurus hensii (Loufoulakari site)

\begin{tabular}{cclc}
\hline RI & RI $_{\text {LITT }}$ & \multicolumn{1}{c}{ Constituents } & $\%$ \\
\hline 838 & 839 & 2-Pentanone,4-hydroxy-4-methyl & 0.1 \\
921 & 926 & Tricyclene & 1.0 \\
932 & 939 & Pinene alpha & 0.4 \\
949 & 954 & Camphene & 2.8 \\
988 & 990 & Myrcene & 0.1 \\
1023 & 1024 & Cymene -ortho & 1.6 \\
1028 & 1029 & Limonene & 6.4 \\
1031 & 1031 & Cineole 1,8 & 0.1 \\
1089 & 1091 & Cymenene para & 0.3 \\
1122 & 1122 & Mentha-2,8-dien-1-ol<trans-para> & 7.4 \\
1137 & 1137 & Mentha-2,8-dien-1-ol<cis-para> & 4.9 \\
1141 & 1141 & Pinocarveol<tans-> & 0.6 \\
1163 & 1164 & Pinocarvone & 0.3 \\
1168 & & Bicyclo[3,3,0]oct-2-en-7-one,6-methyl & 1.1
\end{tabular}




\begin{tabular}{cclc}
1189 & 1189 & Mentha-1(7),8-dien-2-ol <trans-para-> & 11.1 \\
1201 & & NI & 4.2 \\
1208 & 1200 & Caranone<cis-4-> & 0.7 \\
1209 & & Octylacetate & 1.1 \\
1219 & 1216 & Carveoltrans & 4.5 \\
1231 & 1230 & Mentha-1(7),8-dien-2-ol <cis-para-> & 14.1 \\
1234 & 1229 & Carveol <cis> & 0.8 \\
1245 & 1243 & Carvone & 3.2 \\
1255 & 1252 & Piperitone & 0.4 \\
1277 & 1271 & Perillaaldehyde & 0.3 \\
1285 & 1285 & Bornyleacetate & 1.2 \\
1292 & 1294 & Undecanone-2 & 4.9 \\
1307 & 983 & NI & 7.4 \\
1320 & & NI & 2.0 \\
1332 & & NI & 4.5 \\
1434 & 1475 & Néoclovène-beta & 0.0 \\
1495 & 1496 & Tridecanone-2 & 2.1 \\
1671 & 1666 & Intermedeol & 2.7 \\
1698 & 1697 & Pentadecanone-2 & 0.1 \\
1764 & 1763 & Aristolone & 0.3 \\
\hline & & & $\mathbf{9 1 . 9}$ \\
\hline
\end{tabular}

Table 5: Chemical composition on root essential oil (Loufoulakari site)

\begin{tabular}{cclc}
\hline RI & RI $_{\text {LITT }}$ & \multicolumn{1}{c}{ Constituents } & \% FID \\
\hline 838 & 839 & 2-Pentanone,4-hydroxy-4-methyl & 0.6 \\
921 & 926 & Tricyclene & 0.8 \\
925 & 930 & Thujene-alpha & 0.3 \\
932 & 939 & Pinene-alpha & 1.5 \\
949 & 954 & Camphene & 2.7 \\
972 & 975 & Sabinene & 0.3 \\
988 & 990 & Myrcene & 0.6 \\
1024 & 1024 & Cymene<ortho-> & 0.4 \\
1029 & 1029 & Limonene & 8.8 \\
1032 & 1031 & Cineole<1,8-> & 2.6 \\
1084 & 1088 & Terpinolene & 0.1 \\
1121 & 1122 & Mentha-2,8-dien-1-ol <trans-para> & 0.2 \\
1136 & 1137 & Mentha-2,8-dien-1-ol <cis-para> & 0.1 \\
1148 & 1146 & Camphor & 0.1 \\
1181 & 1177 & Terpinen-4-ol & 0.2 \\
1188 & 1189 & Mentha-1(7),8-dien-2-ol<trans-para> & 0.4 \\
1195 & 1188 & Terpineol-alpha & 0.5 \\
1219 & 1216 & Carveol-trans & 0.2 \\
1230 & 1230 & Mentha-1(7),8-dien-2-ol<cis-para> & 0.4 \\
1245 & 1243 & Carvone & 0.2 \\
1255 & 1252 & Piperitone & 0.3
\end{tabular}




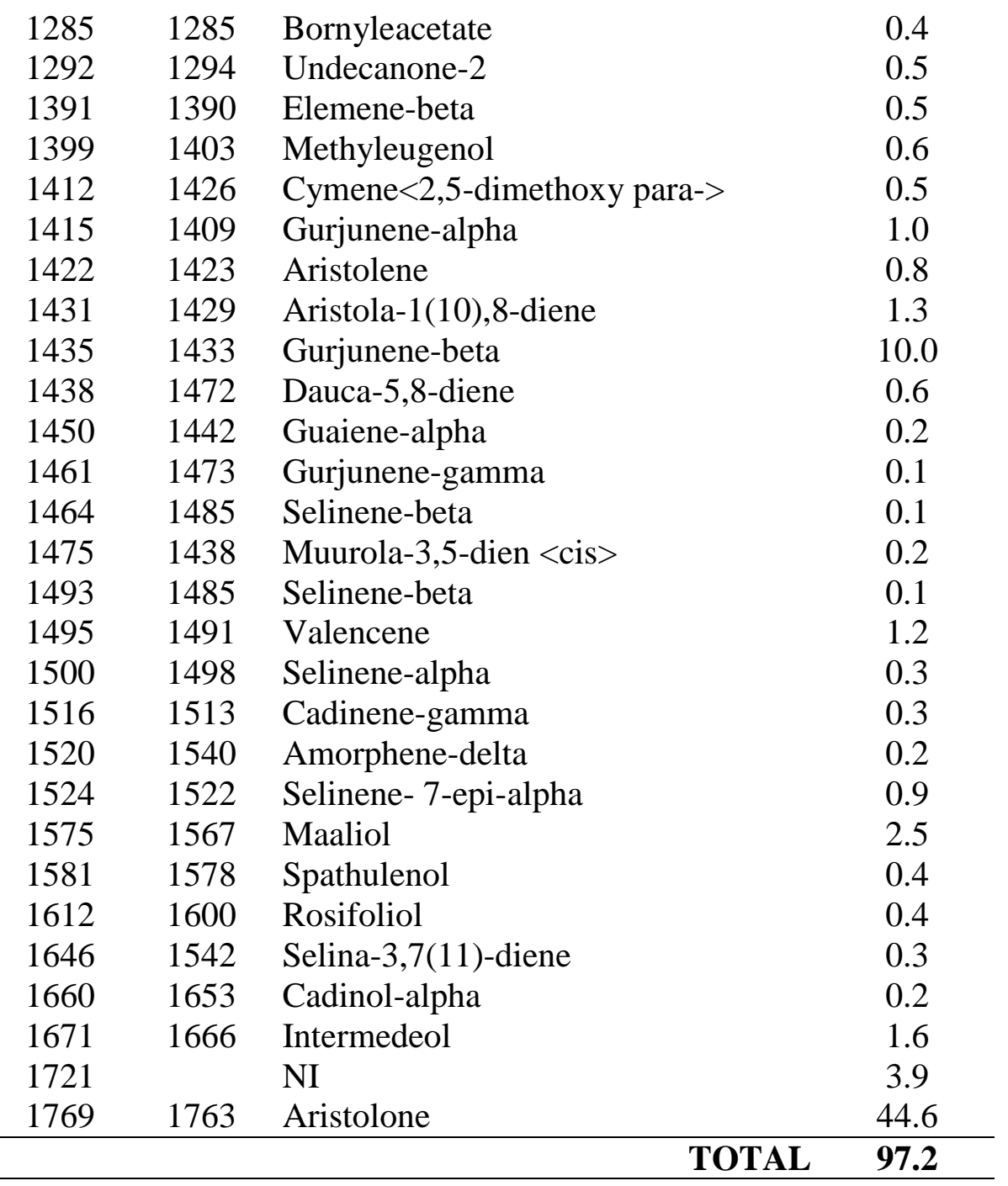

Table 6: Major constituents (**) of essential oils from stems (S) and roots (R) collected at the sites of Loufoulakari (sample 1), Loukoko (sample 2), and Sese (sample 3)

\begin{tabular}{|c|c|c|c|c|c|c|c|}
\hline Sites de récolte & S1* & R1 & S2 & $\mathbf{R} 2 *$ & S3 & $\mathbf{R 3}$ & $* *$ \\
\hline Camphene & 2.8 & 1.1 & 4.9 & 2.6 & 2.3 & 0.8 & I \\
\hline Limonene & 6.4 & 9.7 & 4.9 & 8.8 & 12.8 & 9.7 & II \\
\hline Cineole $\langle 1,8->$ & 0.0 & 3.8 & 0.0 & 2.6 & 0.0 & 5.5 & III \\
\hline $\begin{array}{l}\text { Mentha-2,8-dien-1-ol <trans } \\
\text { para-> }\end{array}$ & 7.4 & 1.2 & 6.5 & 0.2 & 10.1 & 0.8 & IV \\
\hline $\begin{array}{l}\text { Mentha-2,8-dien-1-ol <cis para- } \\
>\end{array}$ & 4.9 & 0.8 & 4.7 & 0.1 & 6.3 & 0.5 & $\mathrm{~V}$ \\
\hline $\begin{array}{l}\text { Mentha-1(7),8-dien-2-ol <trans } \\
\text { para-> }\end{array}$ & 11.1 & 2.3 & 11.2 & 0.4 & 12.2 & 1.1 & VI \\
\hline Carveol trans & 4.5 & 0.8 & 3.9 & 0.2 & 5.1 & 0.4 & VII \\
\hline $\begin{array}{l}\text { Mentha-1(7),8-dien-2-ol <cis } \\
\text { para-> }\end{array}$ & 14.1 & 2.7 & 11.2 & 0.4 & 14.0 & 1.3 & VIII \\
\hline Carvone & 3.2 & 0.8 & 3.2 & 0.2 & 14.0 & 0.4 & IX \\
\hline
\end{tabular}


Undecanone -2

Gurjunene <beta->

Maaliol

Tridecanone 2

Intermedeol

Pentadecanone <2->

Aristolone $\begin{array}{lllllll}4.9 & 2.7 & \mathbf{5 . 7} & 0,10 & \mathbf{3 . 4} & 1.4 & \mathrm{X}\end{array}$

$\begin{array}{lllllll}0.0 & \mathbf{4 . 6} & 0.0 & \mathbf{2 . 2} & 0.0 & \mathbf{6 . 2} & \mathrm{XI}\end{array}$

$\begin{array}{lllll}0.0 & \mathbf{1 . 7} & 0.0 & \mathbf{2 . 5} & 0.0\end{array}$

2.3 XII

$\begin{array}{lllllll}2.1 & \mathbf{1 . 9} & 2.4 & 0.0 & 1.9 & \mathbf{1 . 1} & \text { XIII }\end{array}$

$\begin{array}{lllllll}2.7 & \mathbf{2 . 7} & 2.2 & \mathbf{1 . 6} & 2.0 & \mathbf{1 . 5} & \mathrm{XIV}\end{array}$

$\begin{array}{rrrrrrr}0.0 & 0.0 & 0.0 & 0.0 & 0.0 & 0.0 & \mathrm{XV}\end{array}$

$\begin{array}{lllllll}0.0 & 42.2 & 0.0 & \mathbf{4 4 . 6} & 0.0 & \mathbf{4 1 . 8} & \mathrm{XVI}\end{array}$

* S1 means: stem of sample 1; R2: root of sample 2)

The essential oil from stems was composed of a large number of menthadienol isomers like in Cymbopogon giganteus [15], [16], [17], [30]. The identification of these different isomers is difficult. Garneau et al. [31] determined Kovats indices on two columns and recorded the mass spectra of six menthadienol isomers of known structures, which they synthesised. From these data, after analysis by gas phase chromatography coupled with mass spectrometry, we identified the isomers present in the essential oils studied. They were in decreasing order of content: cis- $p$ mentha-1(7),8-dien-2-ol, trans-p-mentha-1(7),8-dien-2-ol, trans-p-mentha-2,8(9)-dien-1-ol, cis$p$-mentha-2,8(9)-dien-1-ol, and trans-p-mentha-1,8-dien-6-ol (carveol). Then came limonene, 2undecanone, carvone, and 2-tridecanone.

These oils differed appreciably from those extracted from roots, which had lower essential oil contents, more $p$-cymene and intermedeol, and noteworthy levels of aristolone (more than $40 \%$ against $3 \%$ in the aerial parts).

Aristolone was isolated and identified spectrally by NMR spectroscopy and mass spectrometry [10]

This difference can be visualised using a polar coordinate representation (radar plot). One notes that (i) the radar plot of the essential oil from stems differs from that of oil from roots, and (ii) those of oils from the same parts of the plant (stems or roots) are similar. Figure 3 shows radar plots of stem and root essential oils.

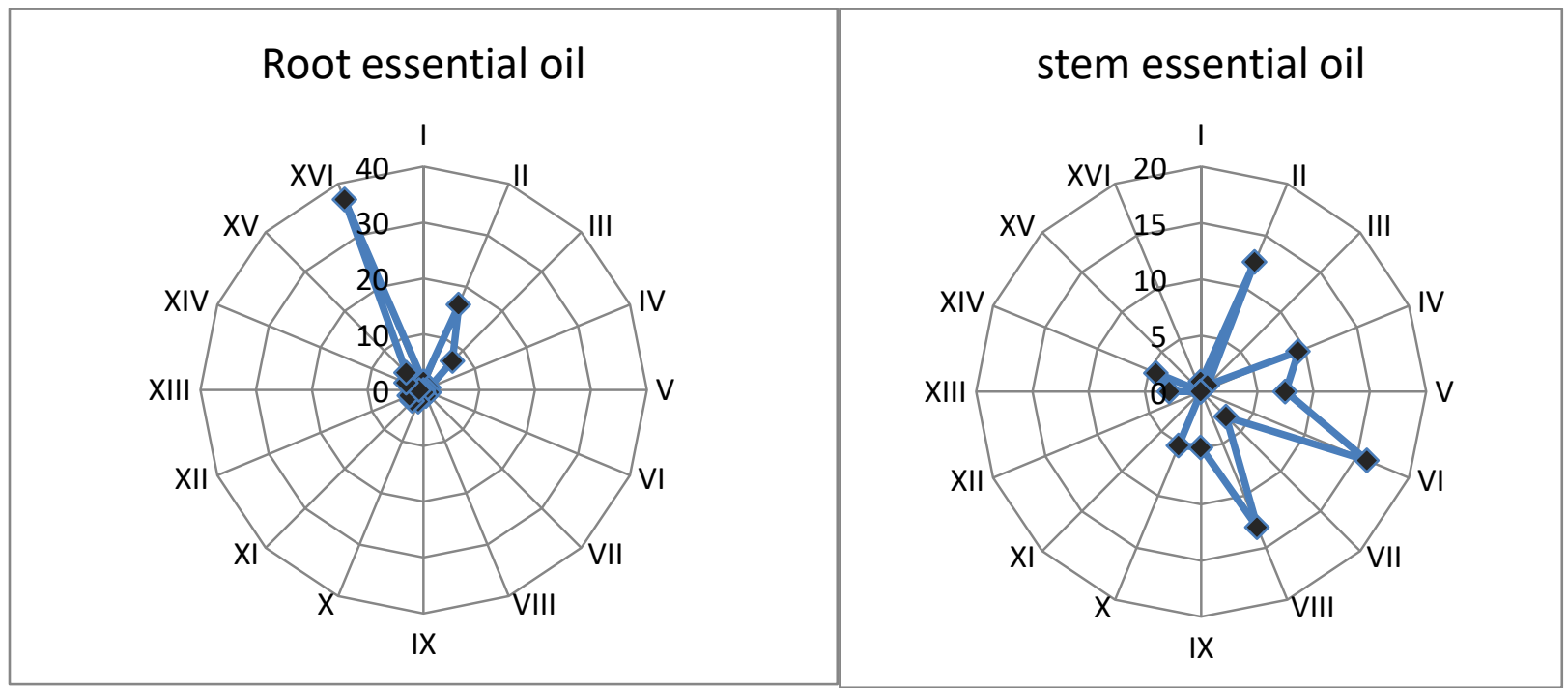

Figure 3: Radar- plots of Stem and root essential oilsextracted from Elionurus hensii 


\subsection{Modelling of Essential Oil Extraction by Hydrodistillation from Elionurus Hensii in A Laboratory Scale}

Steam distillation and water distillation are used to extract useful essential oils from aromatic plant resources.

Skaria et al. [32] distinguish three techniques: (i) hydro-distillation (the plant matter is partially or totally immersed in the distillation water), (ii) steam distillation (steam produced outside the extractor in a steam generator passes through the plant material, which is not in water) et (iii) vapo-hydro-distillation (steam is produced in situ in the extractor, where a grille separates the water from the plant material).

Only hydro-distillation and vapo-hydro-distillation can be used at artisanal scale.

\subsubsection{Hydrodistillation of Elionurus Hensii Stems}

The modelling of the extraction process is in principle complex, but can be simplified by a judicious choice of the factors to be studied. We selected three factors: extraction duration (h), $\mathrm{X}_{2}$; residual water content, $\mathrm{X}_{2}$; state of division $(\mathrm{cm}), \mathrm{X}_{3}$ (tables 1, 2 and 3).

Table 7 recapitulates the experimental matrix and the responses: essential oil content and cumulated $p$-menthadienol content.

Table 7: Experimental matrix and responses (essential oil content and cumulated $p$-menthadienol content).

\begin{tabular}{cccccc}
\hline Run & $\mathbf{X}_{\mathbf{1}}$ & $\mathbf{X}_{\mathbf{2}}$ & $\mathbf{X}_{\mathbf{3}}$ & $\begin{array}{c}\text { Essential oil } \\
\text { yield (\%) }\end{array}$ & $\begin{array}{c}\boldsymbol{p} \text { - menthadienol } \\
\text { Content (\%) }\end{array}$ \\
\hline 1 & -1 & -1 & -1 & 1.0 & 47.9 \\
2 & +1 & -1 & -1 & 0.8 & 45.5 \\
3 & -1 & +1 & -1 & 1.6 & 53.1 \\
4 & +1 & +1 & -1 & 2.0 & 55.6 \\
5 & -1 & -1 & +1 & 0.4 & 45.9 \\
6 & +1 & -1 & +1 & 0.7 & 44.7 \\
7 & -1 & +1 & +1 & 2.1 & 50.2 \\
8 & +1 & +1 & +1 & 2.1 & 56.8 \\
\hline
\end{tabular}

The mathematical equation representing the quantitative yield of the hydrodistillation of stems of Elionurus hensii generated by the model is:

$y=\mathbf{1 . 3 4}+0.07 x_{1}+\mathbf{0 . 6 1} x_{2}+0.02 x_{3}+0.04 x_{1} x_{2}-0.001 x_{1} x_{3}-0.17 x_{2} \mathbf{x}_{3}+0.10 x_{1} x_{2} x_{3}$

With:

$a_{0}=1.34, a_{1}=0.07, a_{2}=0.61, a_{3}=0.02$

$a_{12}=0.04, a_{13}=-0.001, \mathrm{a} 23=-0.17$

$a_{123}=-0.10$ 
This relation shows that the optimum should be located in the experimental domain or very close to it, as the values of an are not very high. The average yield of essential oil we can extract from the experimental set-up is $a_{0}=1.3 \%$.

The influence of residual water content $\left(a_{2}=0.61\right)$ is important in the response, the combined effect of residual water content and state of division of the plant material was favourable $\left(a_{23}=\right.$ $0.17)$. However, we note the very low $a$ values for the other interactions, which can therefore be ignored in practice, especially for small-scale production units.

The mathematical equation representing the cumulated $p$-menthadienol content in the essential oils from stems of Elionurus hensii generated by the model is:

$z=49.95+0.686 x_{1}+\mathbf{3 . 9 6 6} x_{2}-0.563 x_{3}+\mathbf{1 . 5 7 8} x_{1} x_{2}+0.658 x_{1} x_{3}+0.128 x_{2} x_{3}+0.366 x_{1} x_{2} x_{3}$

The average content of cumulated $p$-menthadienols was $49.95 \%$ and the factor, residual water content in plant material, exhibits the most important effect in the response $(+3.966)$. Extraction duration and state of division presents opposite effects: the first is positive $(+0.686)$, the second, negative $(-0.563)$ with a very close magnitude. All interactions are positive and $\mathrm{x}_{1} \mathrm{x}_{2}$ interaction was the most important $(+1.578)$.

\subsubsection{Hydrodistillation of the Elionurus Hensii Roots}

Tables 8 and 9 give the levels of variation of the three variables, the experimental matrix, and the responses (essential oil yield and aristolone content).

Table 8. Levels of variation of variables forthe extraction of essential oils from Elionurus hensii (roots)

\begin{tabular}{lccc}
\hline Level & Extraction duration (h) & Residual water content & State of division (cm) \\
& $\boldsymbol{X}_{\mathbf{1}}$ & $\boldsymbol{X}_{\mathbf{2}}$ & $\boldsymbol{X}_{\mathbf{3}}$ \\
\hline Low $(-1)$ & 1.5 & Low & $<5$ \\
High $(+1)$ & 3 & High & 10 \\
\hline
\end{tabular}

Table 9: Experimental matrix and responses forthe extraction of essential oils from Elionurus

\begin{tabular}{cccccc}
\hline Run & $\mathbf{X}_{\mathbf{1}}$ & $\mathbf{X}_{\mathbf{2}}$ & $\mathbf{X}_{\mathbf{3}}$ & $\begin{array}{c}\text { Essential oil } \\
\text { yield (\%) }\end{array}$ & $\begin{array}{c}\text { Aristolone } \\
\text { Content (\%) }\end{array}$ \\
\hline 1 & -1 & -1 & -1 & 0.5 & 36.9 \\
2 & +1 & -1 & -1 & 0.9 & 38.9 \\
3 & -1 & +1 & -1 & 1.1 & 54.6 \\
4 & +1 & +1 & -1 & 0.8 & 36.7 \\
5 & -1 & -1 & +1 & 0.5 & 37.8 \\
6 & +1 & -1 & +1 & 0.8 & 37.3 \\
7 & -1 & +1 & +1 & 0.5 & 37.3 \\
8 & +1 & +1 & +1 & 0.9 & 50.0 \\
\hline
\end{tabular}

The mathematical equation representing the quantitative yield of the hydrodistillation of roots of Elyonurus hensii generated by the model is: 


\section{Extraction of Elionurus Hensii K. Schum Essential Oil in A Domestic Scale in the "Plateau Des Cataractes" (Congo-Brazzaville) $y=\mathbf{0 . 7 4 7}+\mathbf{0 . 1 1 2} x_{1}+0.0525 x_{2}+0.0575 x_{3}-0.0725 x_{1} x_{2}-0.0375 x_{2} x_{3}+0.0775 x_{1} x_{3}+0.0975 x_{1} x_{2} x_{3}$}

Average yield (0.747), effects of factors $(0.0575-0.112)$ and effects of interactions $(0.0375-$ $0.0775)$ are less important in root essential oil extraction. The extraction duration presents the most important positive effect. Interaction effects are negligeted.

The mathematical equation representing the aristolone content in essential oils of Elyonurus hensii generated by the model is:

$$
z=41.181-0.456 x_{1}+3.466 x_{2}+0.568 x_{3}-0.828 x_{1} x_{2}-0.413 x_{2} x_{3}+3.516 x_{13}+4.133 x_{1} x_{2} x_{3}
$$

Aristolone extraction is more sensitive to the effects of factors and interactions. With an average yield of $41.181 \%$, the extraction was impacted by the residual water content (3.466) and the interaction of extraction duration/state of division (3.516). The three- factor interaction lead to the most important effect on the response (4.133).

\subsubsection{Characterisation of Oils During Extraction}

The analysis of essential oils collected during the execution of the experimental design can yield information on how the different constituents of these oils are extracted in relation to the factors studied.

If light fractions are collected first during a distillation, we can expect to obtain oils rich in light fractions for short times and rich in heavy fractions for long times.

If by contrast all the constituents are collected at the steam temperature, the parts affected first by the steam will be collected together, and we can expect an oil that from the very first drop will have the average composition of the plant's total essential oil.

The multivariate analysis of 16 samples from two experimental designs gave very interesting results.

Principal component analysis (PCA) carried out on the data given in Tables 11 and 12 indicates a very close correlation of variables, mainly around the first principal axis (F1) in the first principal plane (F1F2).

Table 10: Yield (\%) and major component contents (Table $6 *$ ) in essential oils from stems $\left(\mathrm{S}^{* *}\right)$ and roots $\left(\mathrm{R}^{* * *}\right)$ of Elionurus hensii obtained in the execution of the experimental design

\begin{tabular}{|c|c|c|c|c|c|c|c|c|c|c|c|c|c|c|c|c|c|}
\hline & $\%$ & $\mathrm{I}^{*}$ & II & III & IV & $\mathrm{V}$ & VI & VII & VIII & IX & $X$ & XI & XII & XIII & XIV & XV & XVI \\
\hline & 0.4 & & & 0. & & & & & & & & & & & & & \\
\hline $\mathrm{S} 1 * *$ & $\begin{array}{c}0 \\
0.6\end{array}$ & 0.9 & 12.5 & $\begin{array}{l}9 \\
0 .\end{array}$ & 9.4 & 7.5 & 16.0 & 3.2 & 13.1 & 5.0 & 5.2 & 0.0 & 0.0 & 2.8 & 4.3 & 0.5 & 0.5 \\
\hline $\mathrm{S} 2$ & $\begin{array}{c}6 \\
2.1\end{array}$ & 2.9 & 17.6 & $\begin{array}{l}0 \\
0 .\end{array}$ & 10.3 & 6.4 & 14.9 & 2.1 & 13.2 & 3.1 & 5.2 & 0.0 & 0.0 & 3.0 & 5.7 & 0.5 & 0.6 \\
\hline S3 & $\begin{array}{c}0 \\
2.1\end{array}$ & 2.2 & 18.9 & $\begin{array}{l}0 \\
0 .\end{array}$ & 15.4 & 7.1 & 13.7 & 3.1 & 14.0 & 3,22 & 3.2 & 0.0 & 0.0 & 1.2 & 2.8 & 0.5 & 0.0 \\
\hline S4 & $\begin{array}{c}1 \\
0.9\end{array}$ & 2.4 & 14.9 & $\begin{array}{l}0 \\
0 .\end{array}$ & 11.2 & 7.2 & 13.2 & 2.8 & 15.2 & 3,40 & 3.4 & 0.0 & 0.0 & 2.5 & 3.6 & 0.5 & 0.0 \\
\hline S5 & 9 & 2.3 & 17.5 & 0 & 9.4 & 6.5 & 16.2 & 3.1 & 15.8 & 4,83 & 4.8 & 0.0 & 0.0 & 3.4 & 3.9 & 0.5 & 0.0 \\
\hline
\end{tabular}




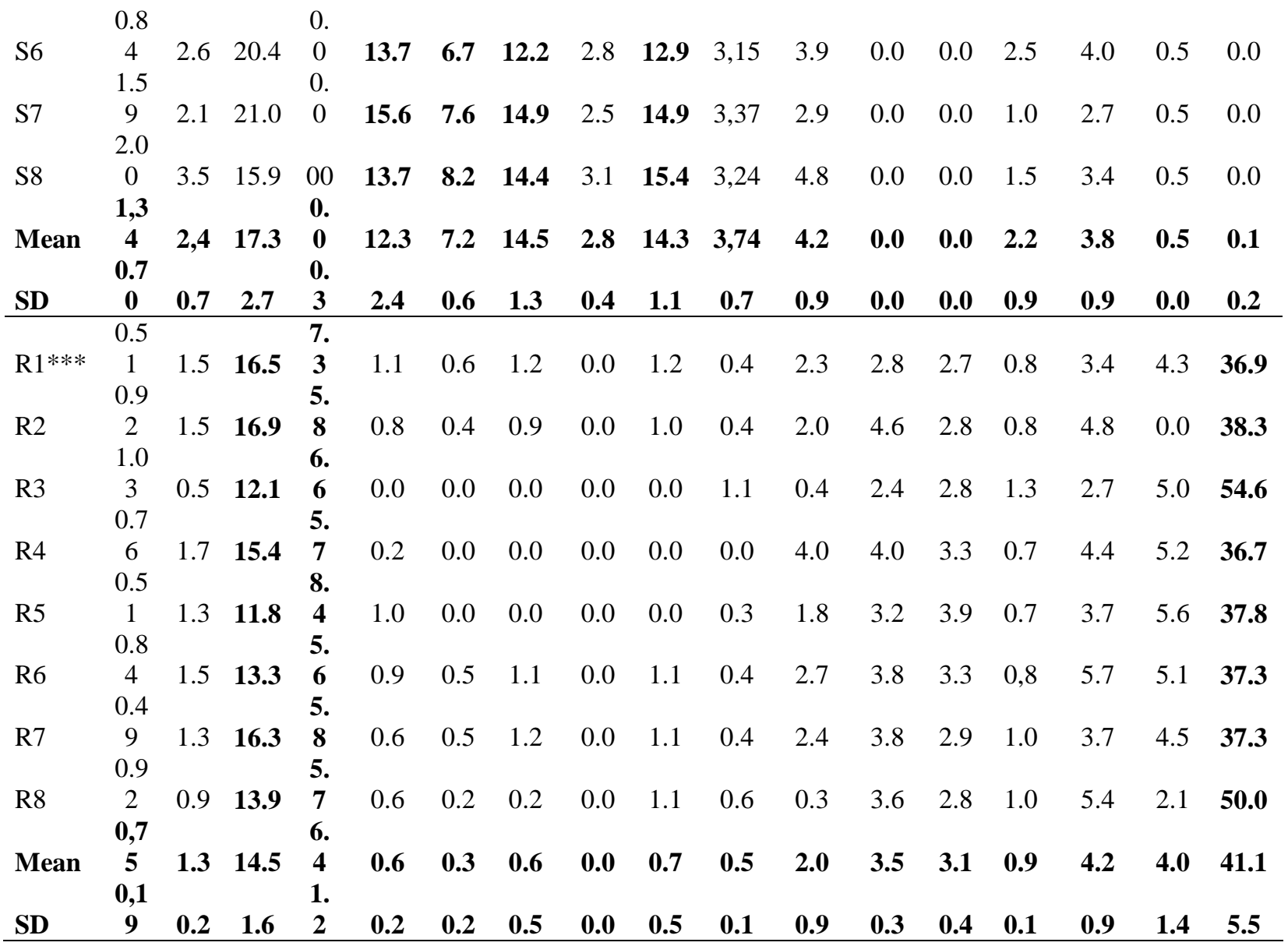

This means that the analysis can be carried out with a much smaller number of variables (constituents of essential oils). Ten of the 16 variables used lie on the correlation circle.

F1 contains $75,25 \%$ of the information on the variability of the essential oils, and $83,14 \%$ on F1F2. The study can therefore be limited to the first principal plane F1F2 (Figure 4).

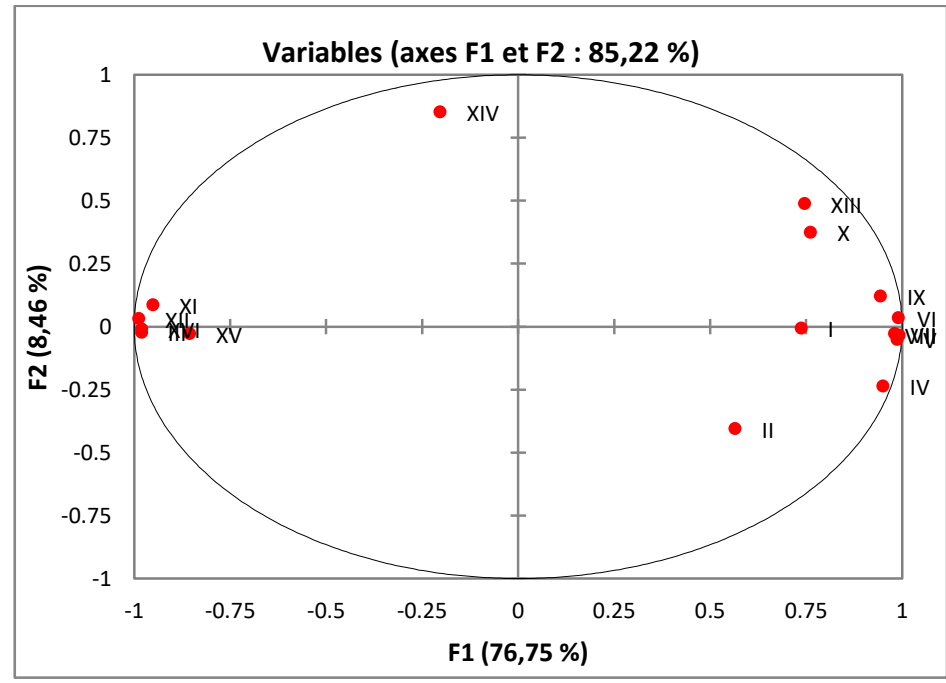

Figure 4: Correlation circle of variables in principal component analysis (PCA) 
The distribution of individuals in the first principal plane F1F2 shows a clear separation between oils of the plant's aerial parts and those of its below-ground parts, suggesting a close similarity of oils from the same plant part, and a marked difference in the oils from the two parts (Figure 5).

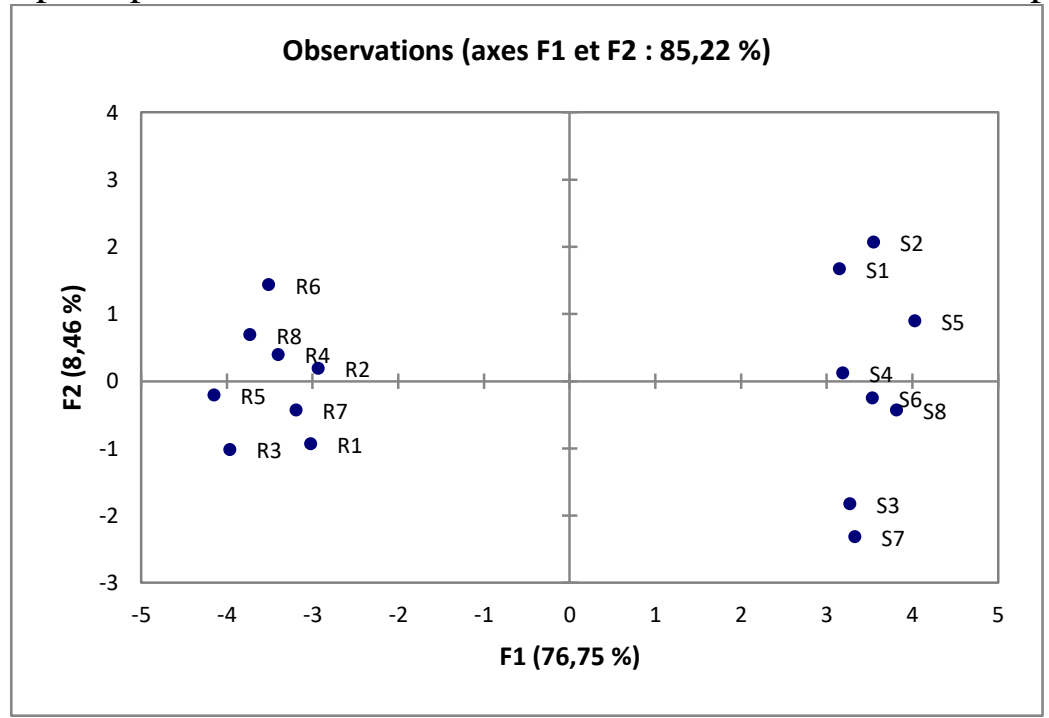

Figure 5: Distribution of individuals (essential oil samples) in principal component analysis (R: roots; S: stems)

Ascending Hierarchical Clustering (AHC) confirms the distribution into two groups each totally separate and homogeneous (oils from stems and oils from roots) (Figure 6, Table 11).

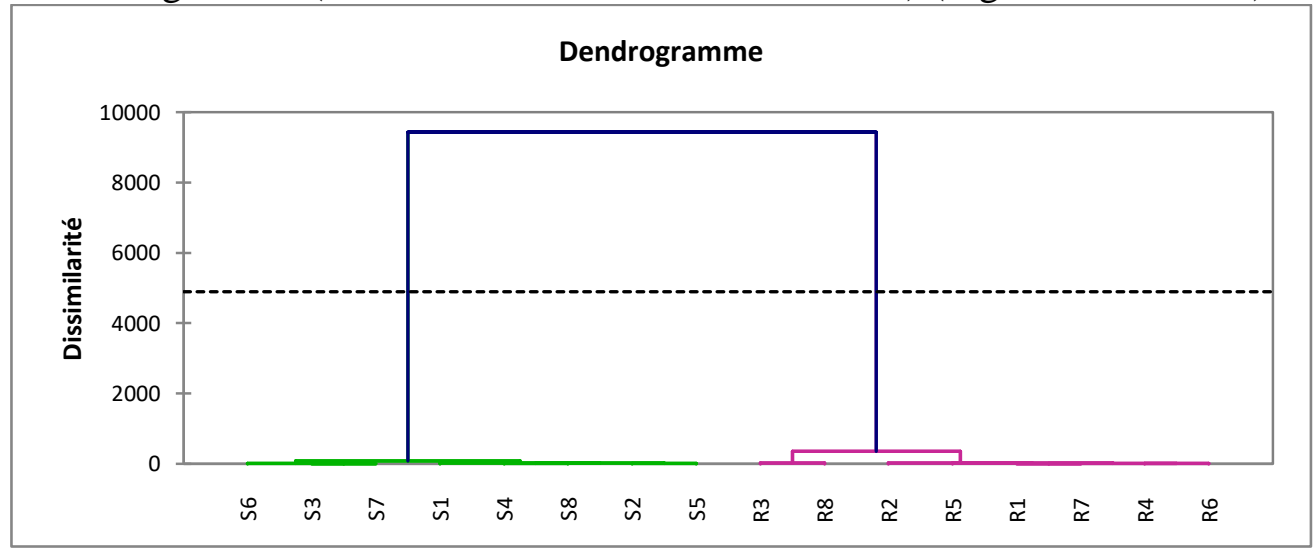

Figure 6: Classes generated by HAC of essential oils

Table 11: Distribution of individuals into classes by HAC

\begin{tabular}{ccc}
\hline Classes & 1 & 2 \\
\hline \multirow{7}{*}{ Individuals } & S1 & R1 \\
& S2 & R2 \\
& S3 & R3 \\
& S4 & R4 \\
& S5 & R5 \\
& S6 & R6 \\
& S7 & R7 \\
& S8 & R8 \\
\hline
\end{tabular}




\subsection{Modelling of the Artisanal Extraction (Hydrodistillation)}

A local extractor, used in a domestic scale in Elionurus hensii essential oil extractions, was tested in following conditions (figure 2, tables 12 and 13).

Table 12: Levels of variation of variables in the artisanal extraction of essential oils from Elionurus hensii (aerial parts).

\begin{tabular}{lccc}
\hline Niveau & Extraction duration (h) & State of division & Extraction water quantity (L) \\
& $\mathbf{X}_{\mathbf{1}}$ & $\mathbf{X}_{\mathbf{2}}$ & $\mathbf{X}_{\mathbf{3}}$ \\
\hline Low $(-1)$ & 1.5 & chopped & 20 \\
High $(+1)$ & 3 & Non chopped & 30 \\
\hline
\end{tabular}

Table 13: Experimental matrix and responses for the extraction of essential oils from Elionurus hensii (aerial parts).

\begin{tabular}{rccccc}
\hline Run & $\mathbf{X}_{\mathbf{1}}$ & $\mathbf{X}_{\mathbf{2}}$ & $\mathbf{X}_{\mathbf{3}}$ & $\begin{array}{c}\text { Essential oil } \\
\text { yield (\%) }\end{array}$ & $\begin{array}{c}\boldsymbol{p} \text { - menthadienol } \\
\text { Content (\%) }\end{array}$ \\
\hline 1 & -1 & -1 & -1 & 0.8 & 52.1 \\
2 & +1 & -1 & -1 & 0.8 & 50.9 \\
3 & -1 & +1 & -1 & 0.7 & 48.2 \\
4 & +1 & +1 & -1 & 0.8 & 47.7 \\
5 & -1 & -1 & +1 & 0.6 & 48.5 \\
6 & +1 & -1 & +1 & 0.7 & 48.1 \\
7 & -1 & +1 & +1 & 0.8 & 49.5 \\
8 & +1 & +1 & +1 & 0.8 & 47.2 \\
& & & & & \\
\hline
\end{tabular}

\subsubsection{Response: Essential Oil Yield}

The average of yield of essential oil extraction is 0.75 . Figure 7 gives the values and the relative importance of the principal and interaction effects of the first order factor.

The principal effects $b_{1}, b_{2}$ and $b_{3}$ are weak and of the same order of magnitude, the two first are positive and the third is negative. The effects of interactions 1-2 and 1-3 are nulls. On figure 8, the diagrams $\mathrm{a}, \mathrm{b}, \mathrm{c}$ and $\mathrm{d}$ the features in dotted strait lines has representing the principal effects, their slopes are identical (similar principal effects) and thus are parallel (absence of interaction effects). The diagrams e and $\mathrm{f}$ illustrate the existence of interaction effects. Then interaction $\mathrm{x}_{2}-\mathrm{x}_{3}$ produces the most important effect on the extraction yield contenu de p-menthadienol and it is positive.

The mathematical expression of the first degree polynom associated to the full factorial design model selected here is:

$$
y=0.75+0.03 x_{1}+0.03 x_{2}-0.02 x_{3}+0.05 x_{1} x_{3}
$$

With a coefficient of regression $\mathrm{R}^{2}=$ which validates a posteriori the model. 


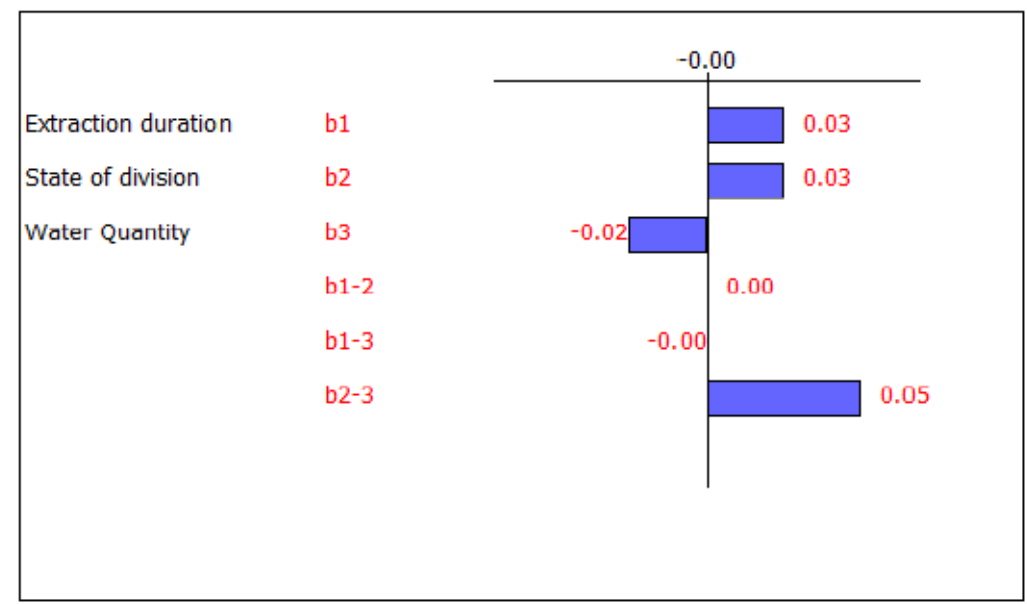

Figure 7: Graphic representation of the coefficient of factor effects (principal and interaction) on the yield of essential oil extraction.

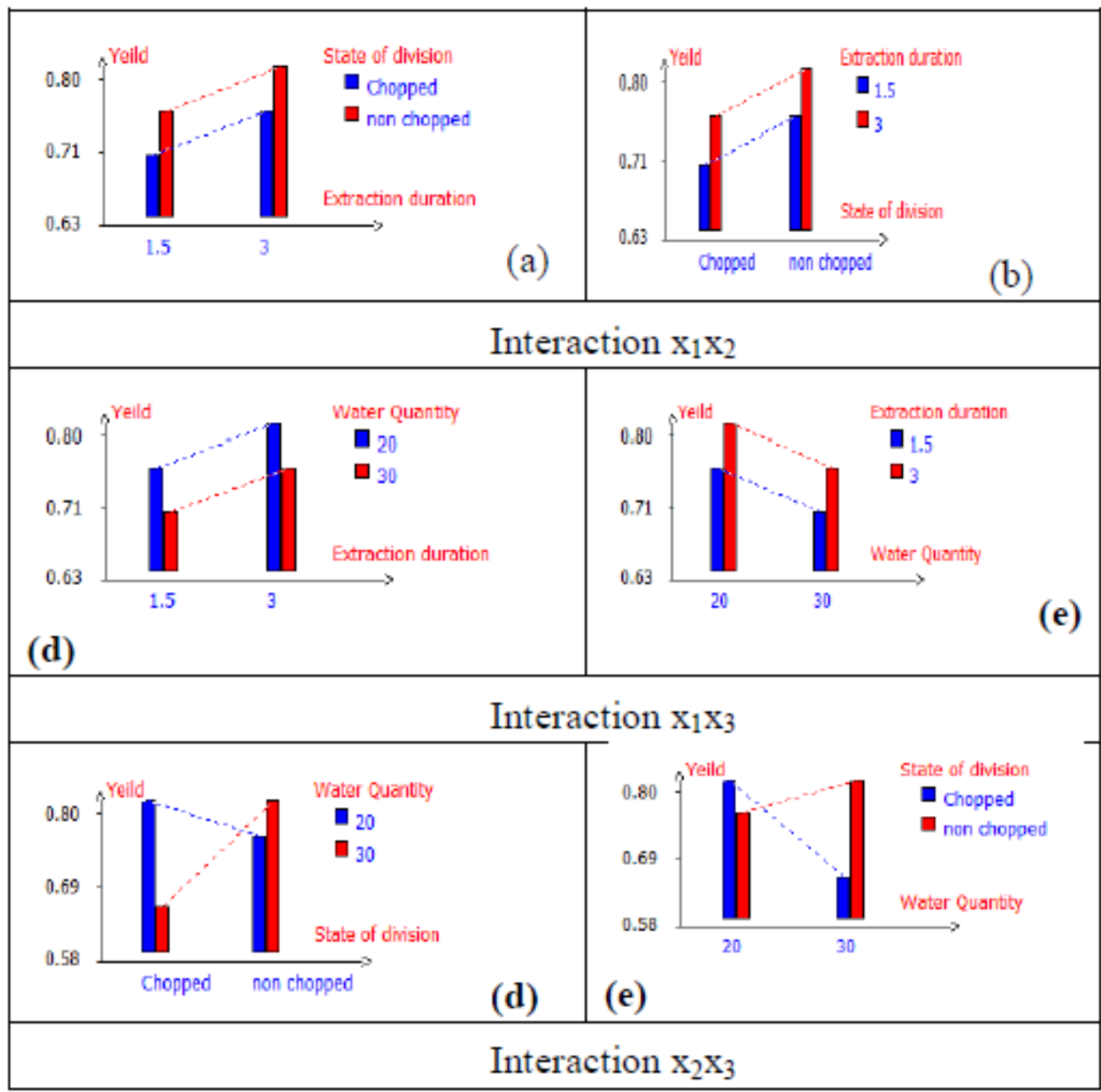

Figure 8: Graphic representation of factor interaction effectson the yield of essential oil extraction. 


\subsubsection{Response : P-Menthadienol Content}

The statistics of the coefficients of the model leading to the coefficient of regression $\mathrm{R}^{2}=0.958$ validate this last, which results mathematically in:

$$
\mathrm{z}=40.0-0.055 \mathrm{x}_{1}-0.88 \mathrm{x}_{2}-0.70 \mathrm{x}_{3}-0.15 \mathrm{x}_{1} \mathrm{x}_{2}-0.13 \mathrm{x}_{1} \mathrm{x}_{3}+0.98 \mathrm{x}_{2} \mathrm{x}_{3}-0.33 \mathrm{x}_{1} \mathrm{x}_{2} \mathrm{x}_{3}
$$

The average of the $p$-menthadienol content is of $40.0 \%$. The content of $p$-methadienols is more sensitive to the principal and interaction effects of the factors; these effects are overall negative. Only the interaction $\mathrm{x}_{2} \mathrm{x}_{3}$ is positive (figure 9).

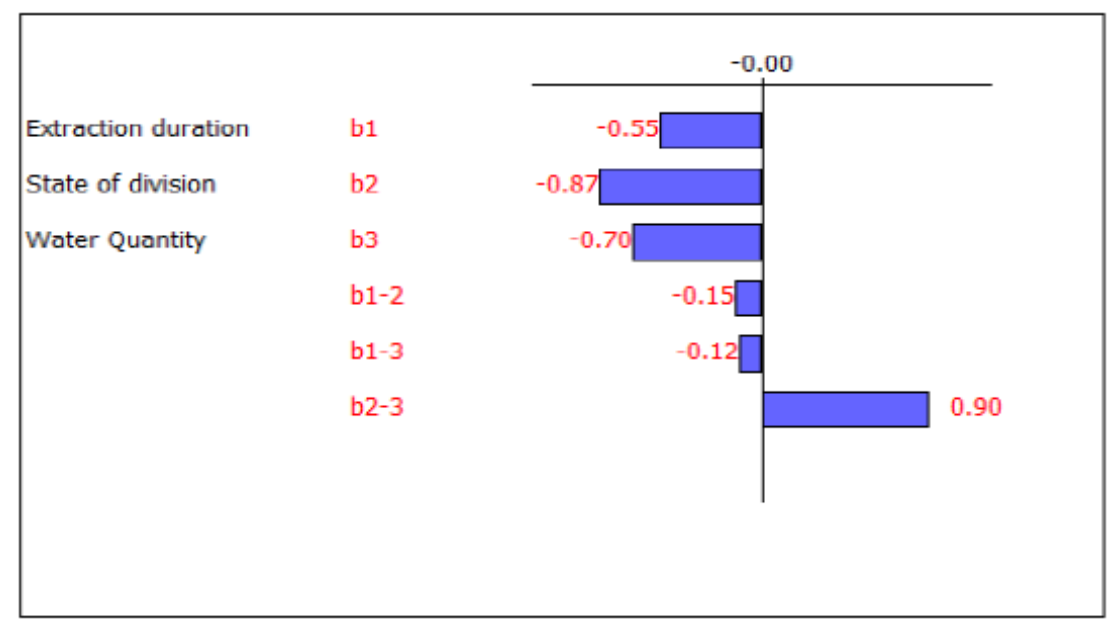

Figure 9: Graphic representation of the coefficient of factor effects (principal and interaction) on $p$-menthadienol content.

\subsubsection{Composition of 8 Samples Extracted Via The Artisanal Scale}

The composition of 8 samples extracted via the artisanal scale were closed similar according to the SD values of the major constituent contents and the representative radar plots of the essential oils (table 14, figure 10).

Table 14: Essential oil composition of samples extracted via the artisanal experimental design (Elionurus hensii stems).

\begin{tabular}{lccccccccc}
\hline $\begin{array}{c}\text { Run (reference of the } \\
\text { sample) }\end{array}$ & $\mathbf{1}(\mathbf{0 3})$ & $\mathbf{2 ( 0 4 )}$ & $\mathbf{3 ( 0 5 )}$ & $\mathbf{4}(\mathbf{0 6})$ & $\mathbf{5}(\mathbf{0 7})$ & $\mathbf{6}(\mathbf{0 8})$ & $\mathbf{7}(\mathbf{0 9})$ & $\mathbf{8}(\mathbf{1 0})$ & $\begin{array}{c}\text { Mean } \\
(\text { SD })\end{array}$ \\
\hline Tricyclene & 1.0 & 1.0 & 1.2 & 0.8 & 1.0 & 1.1 & 0.6 & 0.9 & \\
Pinene alpha & 0.2 & 0.2 & 0.3 & 0.2 & 0.2 & 0.2 & 0.1 & 0.2 & \\
Camphene & $\mathbf{3 . 6}$ & $\mathbf{3 . 3}$ & $\mathbf{3 . 8}$ & $\mathbf{2 . 7}$ & $\mathbf{3 . 1}$ & $\mathbf{3 . 5}$ & $\mathbf{2 . 2}$ & $\mathbf{3 . 1}$ & $3.1(0.4)$ \\
NI & 0.3 & 0.3 & 0.2 & 0.3 & 0.4 & 0.5 & 0.2 & 0.5 & \\
Cymene ortho & 1.7 & 1.6 & 2.1 & 1.7 & 1.9 & 2.1 & 1.2 & 2.0 & \\
Limonene & 2.0 & 1.8 & 1.9 & 1.4 & 1.4 & 1.8 & 1.3 & 1.7 & \\
Cineole 1,8 & 0.2 & 0.2 & 0.3 & 0.2 & 0.1 & 0.2 & 0.2 & 0.3 & \\
Cymenene para & 0.2 & 0.3 & 0.2 & 0.2 & 0.1 & 0.1 & 0.2 & 0.1 & \\
Mentha-2,8-dien-1-ol trans & $\mathbf{1 0 . 0}$ & $\mathbf{9 . 9}$ & $\mathbf{8 . 6}$ & $\mathbf{8 . 6}$ & $\mathbf{8 . 8}$ & $\mathbf{8 . 0}$ & $\mathbf{9 . 4}$ & $\mathbf{8 . 1}$ & $8.9(0.7)$
\end{tabular}


para

Mentha-2,8-dien-1-ol cis

para

Verbenoltrans

6.2

1.1

6.0

5.6

5.5

5.6

5.3

$5.7(0.3)$

NI

0.4

Pinocarvone

0.4

- $\quad 1.0$

1.0

1.0

$5.7 \quad 5.4$

0.3

0.4

$1.0 \quad 1.0$

$\begin{array}{ll}1.3 & 0.4\end{array}$

$\begin{array}{ll}0.3 & 0.3\end{array}$

$0.4 \quad 0.4$

NI

Mentha-1(7),8-dien-2-ol

1.6

0.3

1.8

1.5

1.5

$0.3 \quad 0.3$

trans para

$\begin{array}{lll}18.3 & 18.1 & 18.2\end{array}$

$\mathbf{1 7 . 5}$

Caranone cis-4

17.6

18.1

$1.4-1.7$
-17.3

$\mathbf{1 7 . 3}$

17.8

Menthatriene 1,3,8 para

$0.2 \quad 0.3$

0.7

3.6

2.6

2.5

17.7

3.2

$\begin{array}{llllllll}4.1 & - & - & 5.6 & 4.1 & 5.0 & 5.2 & 4.8\end{array}$

Caranone trans- 4

0.8

0.4

1.0

0.4

$0.4 \quad 0.5$

Mentha-1(7),8-dien-2-ol

15.8

cis para

$17.6 \quad 16,9$

16.

16.6

16.7

16.8

16.5

16.6

$\begin{array}{lllllllll}0.5 & - & 0.7 & 0.6 & 0.9 & 0.8 & 0.8 & 1.0\end{array}$

Carvone

$5.1-$

5.1

5.6

5.0

4.8

$4.9 \quad 5.2$

Piperitone

$0.7 \quad 0.6$

0.6

0.6

0.6

0.7

$0.6 \quad 0.6$

Perilla aldehyde

$0.7 \quad 0.3$

0.3

0.4

0.4

0.4

0.3

0.4

$2.1 \quad 2.0$

$0.6 \quad 0.8$

0.7

0.7

$\begin{array}{ll}0.6 & 0.4\end{array}$

Undecanone 2

$\mathbf{7 . 5} \quad \mathbf{5 . 5}$

2.2

2.1

1.9

2.1

2.0

2.0

$3.2(2.0)$

Tridecanone 2

$\begin{array}{lll}2.6 & 2.6 & 2.4\end{array}$

1.0

3.1

2.8

2.7

3.1

(0.5)

Selina-3,7(11)-diene

$2.6 \quad 2.6$

$2.8 \quad 2.5$

$2.5 \quad 2.5$

$\begin{array}{lllllllll}\text { TOTAL } & 91.1 & \mathbf{7 3 . 8} & \mathbf{7 1 . 9} & \mathbf{8 . 7} & \mathbf{8 2 . 5} & \mathbf{8 3 . 7} & \mathbf{8 1 . 8} & \mathbf{8 3 . 3}\end{array}$

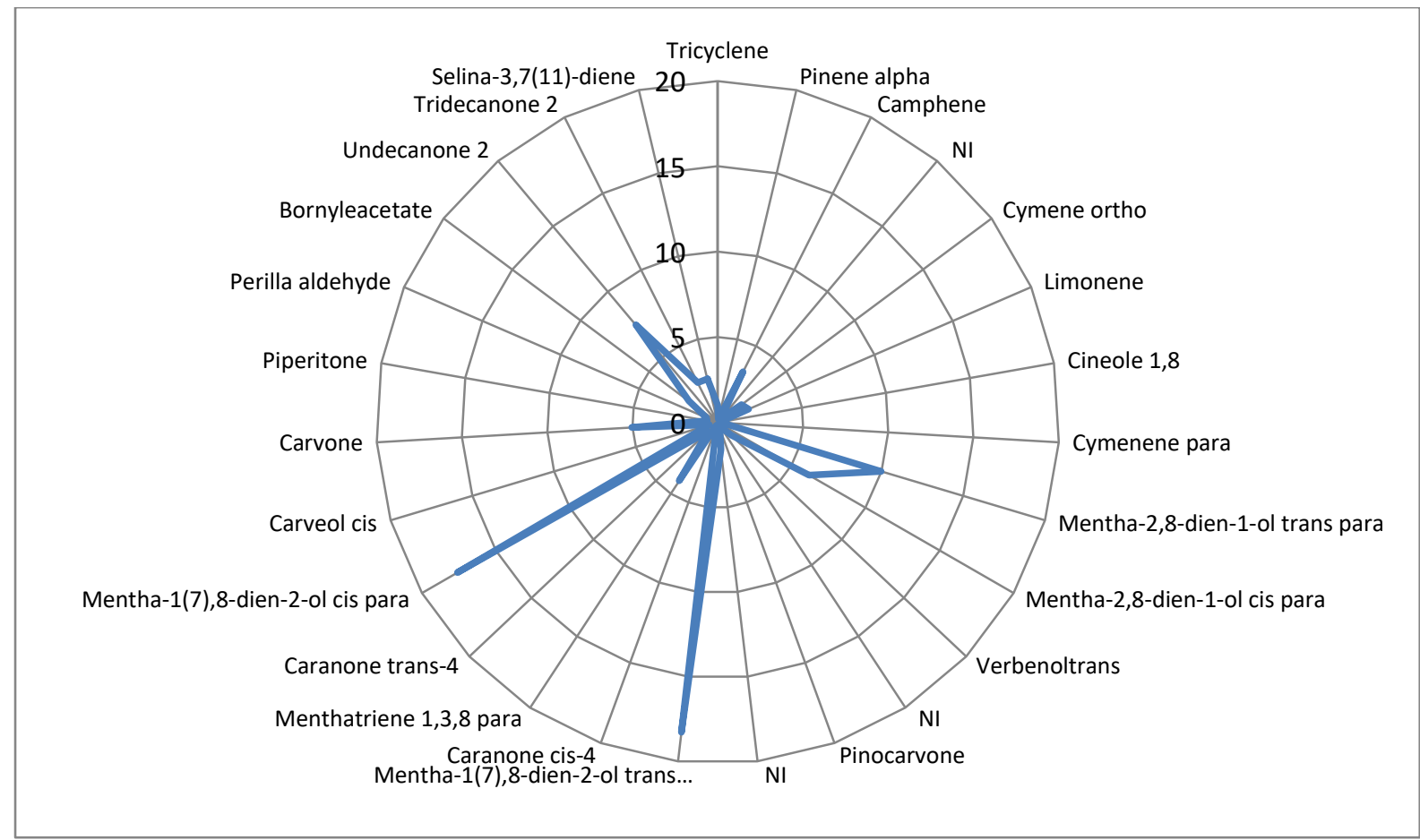

Figure 10: Representative radar plot of the essential oil extracted via the artisanal hydrodistillation from Elionurus hensii stems (similar radar plots for the 8 samples).

http://www.ijoest.com @International Journal of Engineering Science Technologies 


\section{CONCLUSION}

Hydrodistillation is used to extract useful essential oils from aromatic plant resources. Their efficiency depends on both the plant material and the extraction process. It is important to work with homogeneous plant material obtained in the most favourable conditions (collection of plant material when the content and composition of the essential oil is optimal)

The modelling of the extraction process is in principle complex, but can be simplified by a judicious choice of the factors to be studied. We selected three factors for the steam distillation and four factors for the water distillation. These were used as variables in a two-level factorial design. This design, involving a mathematical model in the form of a first degree polynomial, was used to calculate average response, and effects of factors.

The factor considered and the experimental domain selected have very weak influence on the extraction of the essential oil, which is on average $0,75 \%$.

For the aerial part (stems, leaves and flowers) of Elionurus hensii, the values of the factor effects was close to 0 . This means which one is very close to the optimum of extraction. The artisan can thus keep, the current extraction conditions. A finer research of optimum, with the actuel extractor, will not produce any significant profit.

The effects of these same factors have impact more important on the contents of $p$-menthadienol, but non-significant on an artisanal scale.

The composition of the 8 samples resulting from the experimental design have a similar compositions; the factor studied do not have any impact on the quality of oils: nearly $50 \%$ of pmenthadienols, which are responsible known biological properties of this plant.

\section{REFERENCES}

[1] Hess SC, Peres MTLP, Batista AL, Rodrigues JP, Tiviroli SC, Oliveira LGL, Santos CWC, Fedel LES, Crispim SMA, Smania Jr A, Smania EFA,Flach A, Pantaroto S. Evaluation of seasonal changes in chemical composition and antibacterial activity of Elyonurus muticus (Sprengel) O.Kuntze (Gramineae). 30, Quimica Nova, 2007, 370-373.

[2] Scramin S, Saito ML, Pott A, Marques MOM. Essential Oil of Elyonurus Muticus (Sprengel) O.Kuntze (Gramineae). 12, Journal of Essential Oil Research, 2000, 298-300.

[3] Chagonda, L.S., Makanda, C., Chalchat, J.C. The essential oils of wild and cultivated Cymbopogon validus (Stapf) Stapf ex Burtt Davy and Elionurus muticus (Spreng.) Kunth from Zimbabwe. 15, Flavour and Fragrance Journal, 2000, 100-104.

[4] Mevy JP, Bessiere JM, Dherbomez M, Viano J. Composition and Some Biological Activities of The Essential Oils from African Pasture Grass : Elionurus elegans Kunth, 50, . Journal of Agricultural and Food Chemistry, 2002, 4240-4243.

[5] Hefendehl, F.W., Fonseca, L.R. Essential Oil of Elyonurus viridulus. II. Composition of the Oil of a Second Chemical Race. 41, Lloydia, 1978, 283-285.

[6] Dzingirai B, Muchuweti M, Murenje T, Chidewe C, Benhura MAN, Chagonda LS. Phenolic content and phospholipids peroxidation inhibition by methanolic extracts of two medicinal plants: Elionurus muticus and Hypoxis hemerocallidea. 1, African Journal of Biochemistry Research, 2007, 137-141. 
[7] Muchuweti, M., Nyamukonda, L., Chagonda, L.S., Ndhlala, A.R., Mupure, C., Behura, M. Total Phenolic Content and Antioxidant Activity in Selected Medicinal Plants of Zimbabwe. 41, International Journal of Food Science \& Technology, 2006, 33-38.

[8] Yang Y, De Cian M.C, Nsikabaka S, Tomi P, Silou T, Costa J, Paolini J. Volatile Fraction Composition and Total Phenolic and Flavonoid Contents of Elionurushensii-Antioxidant Activities of Essantial Oils and Solvent Extracts. 8 (5), Natural Product Communications, 2013, 655-661.

[9] Silou T, Loubaki L, Figuérédo G, Chalchat JC. Study of Essential Oil Composition of Elyonurus hensii Schum from Congo. 18, Journal of Essential Oil Research, 2006, 518-520.

[10] Loumouamou,A.N., Bikindou, K., Silou, T., Chalard P. and Figueredo G. Essential oil of Elionurus hensii (Schum) from "Plateau des Cataractes" in Congo-Brazzaville: Variation of the Chemical Composition and Evaluation of the Antioxidant Activity. 12(12), Advance Journal of Food Science and Technology 2016, 709-718,

[11] Loumouamou AN, Bikindou K, Bitemou E, Chalard P, Silou T, Figueredo G. Optimization of the extraction of the p-menthadienol isomers and aristolone contained in the essential oil from Elyonurus hensii using a 23 full factorial design. Food Sci Nutr. 2017; 00:1-10. https://doi. org/10.1002/fsn3.459

[12] Loumouamou, A.N., Bikindou, K., Ntalani, H., Silou, T., Chalard P., Danton, O., Delort, L., Decombat, C., Caldefie-Chezet, F., Rubat-Coudert, C. and Figueredo G. Evaluation of the Correlationbetween The Chemical Profile And The Antalgic And Anti-Proliferative Activities Of Essential Oil Of Elionurus Hensii K. Schum. 5(3), Adv Med Plant Res, 2017, 41-46.

[13] Menut C., Bessiere J.M., Samate D., Djibo A.K., Buchbauer G., Schopper B. Aromatic Plants of Tropical West Africa. Xl. Chemical Composition, Antioxidant and Antiradical Properties of the Essential Oils of Three Cymbopogon Species from Burkina Faso. 12 Journal of Essential Oil Research. 2000, 207-212.

[14] Jirovetz, L., Buchbauer, G., Eller, G., Ngassoum, M. B. Maponmetsem, P. M., Composition and Antimicrobial Activity of Cymbopogon giganteus (Hochst.) Chiov. Essential Flower, Leaf and Stem Oils From Cameroon, 19, Journal of Essential Oil Research, 2007, 385 -389.

[15] Ayedoun M.A., Sohounhloué K.D., Menut C., Lamaty G., Bessière J.M. Composition chimique des huiles essentielles de deux espèces de Cymbopogon du Bénin exploitable industriellemen., 8, Bioressources, Energie, Développement Environnement, 1999, 4-6.

[16] Sidibe L., Chalchat J.C. , Garry R.P., Hamara M. ., Aromatic plants of Mali : Chemical Composition Of Two Cymbopogons : Cymbopogon citratus L, Cymbopogon giganteus Chiov. L, Journal of Essential Oil Research, 2001, 110-113.

[17] Boti J.B., Muselli A., Tomi F., Koukoua G., Yao Nguessam T. Costa J., Casanova J., Combined Analysis of Cymbopogon giganteus Chiov. Leaf from Ivory Coast, 9, Competes Rendus Académie des Sciences (fr). Chimie, 2006, 164 -168.

[18] Ouédraogo IW , Boulvin M, Flammand R, Gerbaux P, Bonei-Koulibaly YL Conversion of Natural Aldehydes from Eucalyptus ctriodora, Cymbopogon citratus and Lippia multiflora into oximes : GC-MS and FT-IR analysis, 14, Molécules, 2009, 3275 -3285.

[19] Anonymous, 2010. Développement des filières de commercialisation des huiles essentielles de Eucalyptus citriodora à forte valeur ajoutée, par les communautés villageoises du Congo; Projet CFC/ITTO/80/PD 364/ 05 Rev.4 (I).

[20] Clayton, W.D., Govaerts, R., Harman, K.T., Williamson, H., Vorontsova, M. 2013. World Checklist ofSelected Plant Families. Richmond, UK Available at: http://apps.kew.org/wcsp/.

[21] Sita, P.; Moutsambote, J.-M. Catalogue des plantes vasculaires du Congo, ed. sept. 2005: 1-158. ORSTOM, Centre de Brazzaville, 2000.

[22] Adams RP. Identification of Essential Oil Components by Gaz Chromatography/Quadrupole Mass Spectroscopy. Allured Publishing: Carol Stream, IL. 2001.

[23] McLafferty, F.W. and Stauffer, D.B. The Wiley/NBS Registry of Mass Spectral Data; John Wiley and Sons, New York.1989. 
[24] König WA, Hochmuth DH, Joulain D. Terpenoids and Related Constituents of Essential Oils. Library of MassFinder 2.1. University of Hamburg, Institute of Organic Chemistry: Hamburg, Germany. 2001.

[25] NIST: National Institute of Standards and Technology. PC Version 1.7 of The NIST/EPA/NIH Mass Spectra Library, Perkin-Elmer, Norwalk, CT, National Institute of Standards and Technology, NIST Chemistry WebBook, NIST Standard, 1999.

[26] Denny, E.F.K., Field distillation for herbaceous oils, 2d edition, Denny \& Mckenzie Associate, Lilyte, (Australia) 1991.

[27] Goupy, J. Introduction aux plans d'expériences, 2ème Edition, Dunod, Paris. 2001

[28] Davies, O.L. Design and analysis of industrial experiments, Olivier \& Boyd, London. 1954.

[29] Ortigosa, C., Planification expérimentale en chimie, 7, Bulletin du CIFEC, 1993, 46 - 57.

[30] Ouamba J.M., Valorisation chimique des plantes aromatiques du Congo, These Université de Montpellier II, 1991.

[31] Garneau F X, Collin G ;,Gagnon H., Jean F.I., Chalchat J.C. Mass spectra and retention indices of six menthadiénols. , Journal of Essential Oil Research, 1997, 491-493.

[32] Skaria SP, Joy PP,Mathew G, Mathew S, Joseph A Lemongrass in Handbook of herbs and spices, Peter KV Edit, vol 2, second edition Woodhead Publishing Limited, 2012, Oxford, Cambridge, Philadelphia, New Delhi. 2012.

*Corresponding author.

E-mail address: thsilou@ yahoo.fr 